\title{
Biodiversity of major bacterial groups in association with agarwood (Aquilaria crassna) in Khanh Hoa province, Vietnam
}

\author{
Đa dạng sinh học các nhóm vi khuẩn chính trên Trầm hương Khánh Hòa, Việt \\ Nam \\ Research article
}

Nguyen, Thi Thanh Tra; Nguyen, Van Duy*

Institute of Biotechnology and Environment, Nha Trang University, 02 Nguyen Dinh Chieu, Nha Trang, Khanh Hoa, Vietnam

\begin{abstract}
Agarwood mainly formed by Aquilaria species is an economically and pharmaceutically important natural product used for the production of incense, perfumes and traditional medicines in Asia. Endophytic bacteria are potentially important in producing pharmaceutical compounds found in the plants. The aim of this research is to isolate, classify and identify major endophytic bacteria groups associated with agarwood of Aquilaria crassna species in Khanh Hoa province, Vietnam. Agarwood samples were collected and surface-sterilized, and total endophytic bacteria were isolated on Tryptic Soy Agar by the spread plate method. Major bacterial groups were classified according to the Bergey's system. The 16S rRNA gene fragments were amplified using PCR method, and bacterial isolates were identified using this gene sequence similarity based method. The results showed that from $0.121 \mathrm{~g}$ of agarwood, total 26 bacterial isolates were purified and divided into 7 separated groups, in which the group II of Gram-positive spore-forming bacteria was the most dominant. Especially, two dominant strains, T14 of group II, and T15 of group VII, were identified as Bacillus pumilus and Alcaligenes faecalis, respectively. To our knowledge, it is the first time that biodiversity of bacterial endophytes associated with agarwood from Aquilaria crassna in Vietnam has been reported, which requires of further study to understand the relationship of endophytic bacteria to agarwood-producing Aquilaria crassna species as well as explore their potential applications towards the development of valuable bioactive compounds.
\end{abstract}

Trầm huơng, chủ yếu được tạo ra tù̀ các loài cây Dó (Aquilaria), là một sản phẩm tụ nhiên có giá trị kinh tế và y học đã được sủ̉ dụng để sản xuất hương, nước hoa và các dược phẩm truyền thống $o^{*}$ châu Á. Vi khuẩn nội cộng sinh thực vật được cho là một nguồn quan trọng cho các dược phẩm có nguồn gốc thực vật. Mục tiêu của nghiên cứu này là nhằm phân lập, phân loại và định danh các nhóm vi khuẩn chính trên Trầm hương Khánh Hòa, Việt Nam. Các mẫu Trầm hương được thu nhận và vô trùng bề mặt dùng để phân lập vi khuẩn tổng số trên môi truòng TSA bằng phuơng pháp trải đĩa. Các nhóm vi khuẩn chính được phân loại dựa theo hệ thống chuẩn Bergey. Đoạn gen mã hóa $16 \mathrm{~S}$ rRNA được khuếch đại bằng phương pháp PCR, và các chủng vi khuẩn được định danh bằng phép so sánh độ twơng đồng trình tụ của đoạn gen này. Kết quả cho thấy tù $0,121 \mathrm{~g}$ mẫu trầm hương, chúng tôi đã phân lập được 26 chủng vi khuẩn và phân chúng vào 7 nhóm chính, trong đó nhóm II bao gồm các vi khuẩn Gram duơng sinh bào tủ là nhóm chiếm ưu thế nhất. Đặc biệt, có 2 chủng wu thế là chủng T14 thuộc nhóm II và chủng T15 thuộc nhóm VII đã được định danh tuoong úng là Bacillus pumilus và Alcaligenes faecalis. Đây là nghiên cứu đầu tiên về đa dạng sinh học của các nhóm vi khuẩn chính trên Trầm hương Khánh Hòa. Vì vậy, cần có nhũng nghiên cứu tiếp theo nhằm tìm hiểu mối quan hệ giũa các vi khuẩn nội cộng sinh với cây Dó bầu (Aquilaria crassna) tạo trầm cũng nhu khai thác nhũng ứng dụng tiềm năng của các vi khuẩn này theo huoóng phát triển các hoạt chất sinh học có giá trị.

Keywords: agarwood, Aquilaria crassna, Bacillus pumilus, bioactive compounds, endophytic bacteria 


\section{Introduction}

Agarwood (gaharu, jinko, aloeswood, oud, or tram huong in Vietnamese), which is the fragrant resinous wood, is an important commodity from Aquilaria and Gyrinops species in the family Thymelaeaceae and has been used as an incense, perfume, and multi-functional pharmaceutical in traditional medicine throughout Asia (Eurlings et al., 2010). Its pharmacological functions include sedative, analgesic, anti-inflammatory, anti-microbial, immunomodulatory, and wound healing properties. Also, agarwood is used as a digestive and laxative in medicine (Bhore et al., 2013; Huang et al., 2013). Due to increasing demand, agarwood has become very rare in the wild. Recently, all Aquilaria species are listed in Appendix II of the Convention on International Trade in Endangered Species of Wild Fauna and Flora (CITES) to improve control of commercial agarwood trade. Aquilaria crassna Pierre ex Lecomte, 1915, is the species that occurs in Vietnam, Cambodia, Laos, and central Thailand (Zhang et al., 2008).

Endophytes are microorganisms that live inside plants (inter or intra cellular in nature) without causing any plant disease (Bhore et al., 2013). Recent studies have indicated that endophytic bacteria are common among the resident microflora of the healthy inner tissues of various species of plants (Tian et al., 2007). Because the function of endophytic bacteria in the plants are poorly understood, isolation and identification of these bacterial strains can contribute into understanding the relationship between microbes and plants, especially agarwood-producing Aquilaria species, as well as the discovery of novel bacterial species. For example, a novel species Micrococcus endophyticus was uncovered from surface-sterilized Aquilaria sinensis roots (Chen et al., 2009). Recent results of 16S rRNA gene sequences analysis have revealed 18 different types of endophytic bacteria are associated with seven Aquilaria species in Malaysia (Bhore et al., 2013). In the present study, we report the results of isolation, primary classification and identification of major bacterial groups associated with agarwood produced by the economically and pharmaceutically important Aquilaria crassna species in Vietnam.

\section{Materials and methods}

\subsection{Agarwood sampling and bacterial isolation}

A total of $0.121 \mathrm{~g}$ of dark brown and soft agarwood (Aquilaria crassna) supported by Agarwood Society of Khanh Hoa province, Vietnam was used for bacterial isolation. The surface-sterilization of the collected agarwood samples was carried out as described elsewhere (Bhore et al., 2013). Total bacteria were isolated by the spread plate method. Agarwood samples were homogenized using tissue grinders and vortexed in sterile saline solution $(8.5 \mathrm{~g} / 1 \mathrm{NaCl})$. Tenfold serial dilution of samples was prepared and plated on Tryptic Soy Agar (TSA) (Difco, Detroit, MI, USA). All plates were incubated for $24-48 \mathrm{~h}$ at $37^{\circ} \mathrm{C}$.

\subsection{Morphological analysis and preliminary classification of bacteria isolates}

Pure cultures of bacteria isolates were obtained by means of repeated streaking on plates containing TSA. The purified strains were picked and then maintained on TSA slants at $4^{\circ} \mathrm{C}$ and as $20 \%(\mathrm{w} / \mathrm{v})$ glycerol suspensions at $-70^{\circ} \mathrm{C}$. Gram staining was carried out using the standard Gram reaction and was confirmed with the $\mathrm{KOH}$ test (Moaledj, 1986). Morphological analysis was carried out by using light microscopy (BH-2, Olympus) with cells from exponentially growing cultures. Colony morphology was observed on TSA after incubation at $37^{\circ} \mathrm{C}$ for $2-3$ days.

Preliminary classification of bacteria isolates into major groups was performed according to Bergey's Manual of Determinative Bacteriology (Holt, 1994).

\subsection{Genomic DNA extraction and PCR amplification}

Total DNA of bacterial isolates was extracted by the alkaline lysis method using the kit Wizard $® S V$ Genomic DNA Purification System (Promega). Purified DNA samples were used as templates in the PCR reactions. The specific primers used for the amplification of the $16 \mathrm{~S}$ rRNA gene (27F and 1492R) (Luan et al., 2007). The PCRs were performed in $50 \mu \mathrm{l}$ reactions containing $2 \mu 1$ $(10 \mathrm{ng})$ of template DNA, $0.5 \mu \mathrm{M}$ each primer, $1.5 \mathrm{mM}$ $\mathrm{MgCl} 2,50 \mu \mathrm{M}$ each dNTP, and $1 \mathrm{U}$ Taq DNA polymerase along with $1 \mathrm{X}$ Taq buffer. Amplification was performed in a DNA thermal cycler (Bio-Rad Laboratories, Irvine, CA, USA) with an initial denaturing step for 10 min at $95^{\circ} \mathrm{C}$ and 40 cycles of 1 min per cycle at $95^{\circ} \mathrm{C}, 1$ min at $55^{\circ} \mathrm{C}$ and $2 \mathrm{~min}$ at $72^{\circ} \mathrm{C}$, followed by $5 \mathrm{~min}$ at $72^{\circ} \mathrm{C}$. The amplified products were visualized in a $1 \%$ weight per volume $(\mathrm{w} / \mathrm{v})$ agarose gel $(0.5$ Trisborateethylene-diamine-tetraacetic acid buffer, $\mathrm{pH}$ 8.0) stained with ethidium bromide.

\subsection{Gene sequencing and phylogenetic analyses}

The PCR products of bacterial isolates were purified using the PCR Clean Up System Kit (Promega) and used as template for sequencing using the Big Dye terminator cycle sequencing kit (Applied Biosystems, Foster City, CA, USA) on an ABI 3130XL DNA Sequencer (Applied Biosystems) in Nam Khoa Biotek (Hochiminh city, Vietnam) and an ABI 3730XL DNA Sequencer (Applied Biosystems) in Marcrogen (Soul, Korea). Partial gene sequences of bacterial isolates and reference sequences available in GenBank were used for sequence analysis at the National Center for Biotechnology Information (NCBI) using BLAST (http://www.ncbi.nlm.nih.gov/BLAST). Gene sequences were aligned using ClustalW (Larkin et al., 2007), and regions with gaps were removed using BioEdit (Hall, 1999). Model selection was used to determine the best fit model with the lowest Bayesian Information Criterion 
score for Neighbor Joining analysis, which was then used to construct a phylogenetic tree using the MEGA program ver. 5.2.1 (Tamura et al., 2011). The robustness of the tree topology was tested by bootstrap analysis with 1000 resamplings (Felsenstein, 1985).

\section{Results}

\subsection{Isolation of bacteria in association with agarwood}

The average total aerobic bacterial counts were recorded from the agarwood samples as $7.5 \times 10^{4} \mathrm{CFU} / \mathrm{g}$. A total of 26 isolates were purified and named from T1 to T21 and T23 to T27.

\subsection{Morphological diversity of bacterial isolates from agarwood}

Colony and cell morphological characteristics of 26 isolates were illustrated in Figure 1 and Figure 2. Gram staining indicated that 16 isolates were Gram-positives and the remaining isolates were negatives (Figure 1). It is worth noting that more than a half of the number of Gram-positives including T7, T11, T12, T13, T14, T18, T21, T26 and T27 are endospore-forming bacteria, suggesting them as Bacillus or Clostridium.

The isolates T8, T9, T16, T20 and T23 indicated yellow colonies on TSA, whereas the T17 and T25 were green (Figure 2). All remaining isolates showed opalescent colonies. Interestingly, the isolates T17, T23, T24, T25 and T26 were found to modify the medium into green while yellow pigment was produced by the T27.

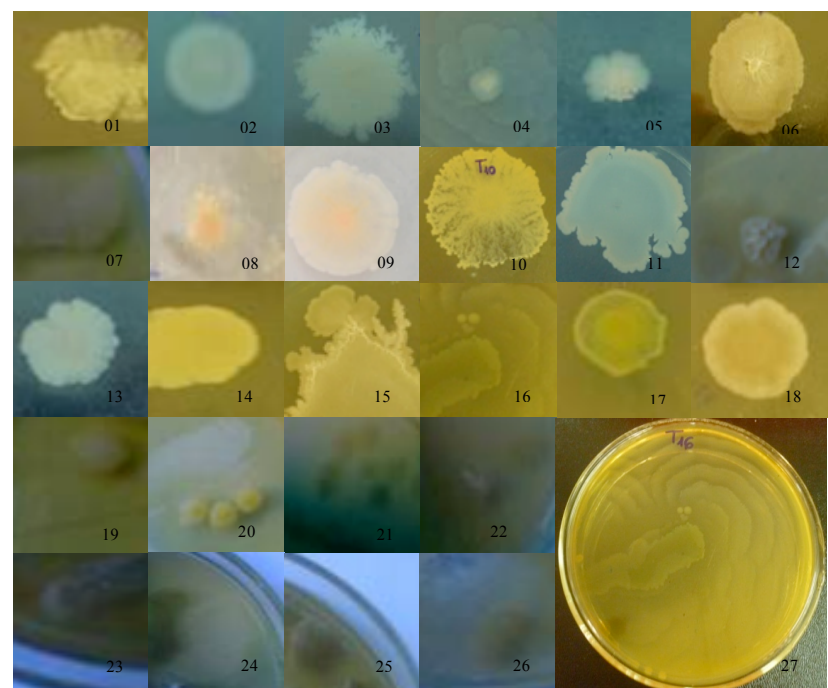

Figure 1. Various colonies formed by bacterial isolates from agarwood (Aquilaria crassna)

Numbers 01-26 indicated colonies of isolates T1-T21, T23-T27, respectively. Number 27 showed mobility of T16.

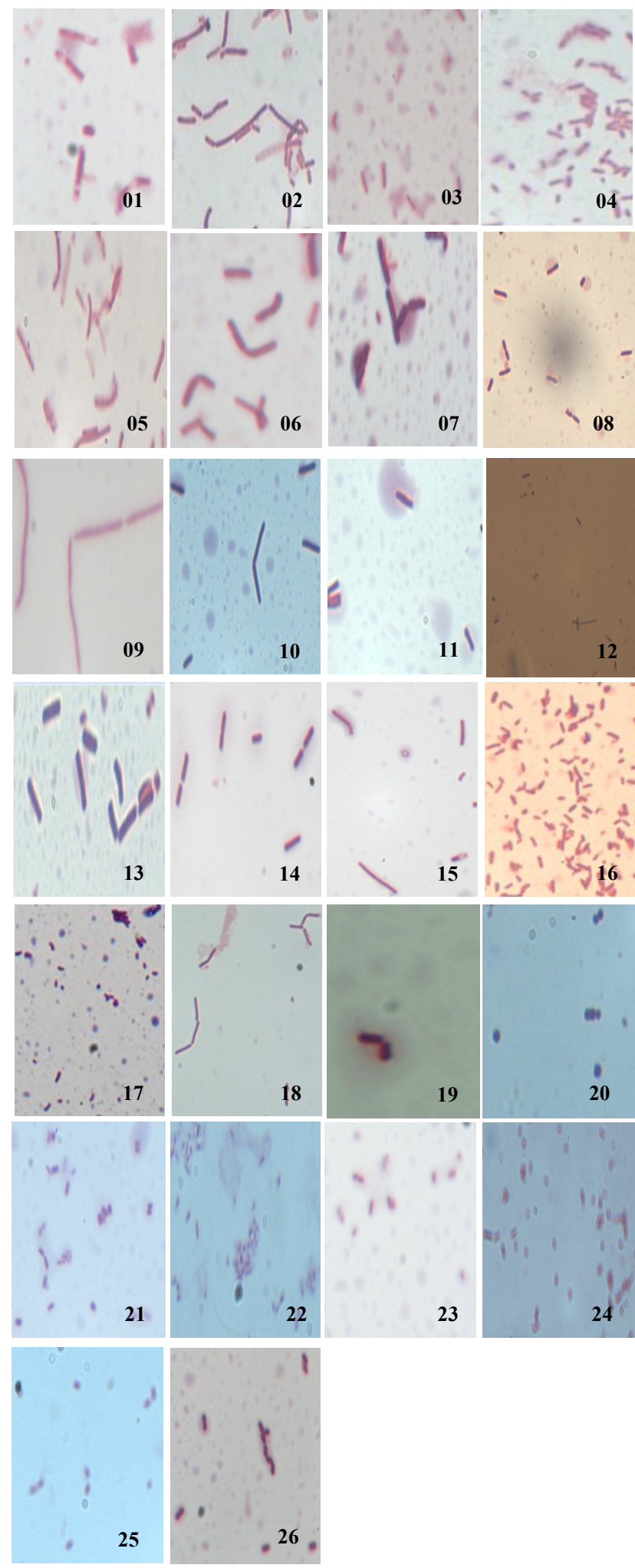

Figure 2. Gram-stain micrograph of bacterial isolates from agar wood (Aquilaria crassna)

Numbers 01-26 indicated cells of isolates T1-T21, T23$\mathrm{T} 27$, respectively.

\subsection{Classification of major bacterial groups isolated from agarwood}

According to Bergey's classification system, 26 isolates were divided into 7 different major groups of eubacteria (Table 1). The most dominant group is the group II with 9 
isolates which indicate rod-shaped, spore-bearing, large and uniform cells of Bacillus and Clostridium.

Table 1. Major bacterial groups in association with agarwood (Aquilaria crassna) in Khanh Hoa province (Vietnam) according to the Bergey's classification system

\begin{tabular}{|c|c|c|c|c|c|}
\hline Group & Strains & $\begin{array}{c}\text { Gram } \\
\text { staining }\end{array}$ & Cell characteristics & $\begin{array}{l}\text { Endospore } \\
\text { production }\end{array}$ & $\begin{array}{l}\text { Representative genera in the } \\
\text { Bergey's system }\end{array}$ \\
\hline $\mathrm{I}$ & $\mathrm{T} 20$ & + & $\begin{array}{l}\text { Round in clusters } \\
\text { \& tetrads }\end{array}$ & - & $\begin{array}{l}\text { Staphylococcus } \\
\text { Micrococcus } \\
\text { Peptococcus }\end{array}$ \\
\hline II & $\begin{array}{c}\text { T7, T11, T12, T13, } \\
\text { T14, T18, T21, T26, } \\
\text { T27 }\end{array}$ & + & $\begin{array}{l}\text { Rod-shaped, spore- } \\
\text { bearing, large, uniform }\end{array}$ & + & $\begin{array}{c}\text { Bacillus } \\
\text { Clostridium }\end{array}$ \\
\hline III & $\begin{array}{c}\mathrm{T} 2, \mathrm{~T} 8, \mathrm{~T} 10, \mathrm{~T} 17 \\
\mathrm{~T} 19, \mathrm{~T} 23\end{array}$ & + & Filamentous cell & - & $\begin{array}{l}\text { Erysipelothrix } \\
\text { Lactobacillus } \\
\text { Eubacterium }\end{array}$ \\
\hline IV & $\mathrm{T} 4, \mathrm{~T} 5, \mathrm{~T} 16$ & - & $\begin{array}{l}\text { Medium-sized } \\
\text { cocco-bacillary }\end{array}$ & - & $\begin{array}{l}\text { Acinetobacter } \\
\text { Moraxella }\end{array}$ \\
\hline V & $\mathrm{T} 24, \mathrm{~T} 25$ & - & Tiny cocco-bacillary & - & $\begin{array}{c}\text { Brucella } \\
\text { Bordetella } \\
\text { Bacteroides }\end{array}$ \\
\hline VI & T6, T9 & - & $\begin{array}{l}\text { Pleomorphic } \\
\text { coccobacillary } \\
\& \text { filamentous }\end{array}$ & - & $\begin{array}{c}\text { Haemophilus } \\
\text { Bacteroides } \\
\text { Pasteurella } \\
\text { Francisella } \\
\text { Actinobacillus } \\
\text { Eikenella } \\
\text { Cardiobacterrium } \\
\text { Flavobacterium }\end{array}$ \\
\hline VII & $\mathrm{T} 1, \mathrm{~T} 3, \mathrm{~T} 15$ & - & $\begin{array}{l}\text { Uniformly } \\
\text { Bacillary }\end{array}$ & - & $\begin{array}{c}\text { Enterobacteriaceae } \\
\text { Pseudomonas } \\
\text { Aeromonas } \\
\text { Alcaligenes } \\
\text { Chromobacterium }\end{array}$ \\
\hline
\end{tabular}

\subsection{Molecular identification of two dominant strains from agarwood}

Two dominant strains (T14 and T15) were selected for further molecular identification into genus and species. The partial 16S rRNA gene of the strains T14 and T15 were sequenced with total 1340 and $1275 \mathrm{bp}$, respectively BLAST analysis of the $16 \mathrm{~S}$ rRNA gene sequence of T14 revealed $99.6-100 \%$ homology to type strains and others of the most related species including Bacillus pumilus, Bacillus altitudinis, Bacillus stratosphericus, Bacillus aerophilus, Bacillus altitudinis and Bacillus safensis. Phylogenetic analysis was shown in Figure 3, which confirmed this evolution relationship. Further analysis of biochemical characteristics using API 50 CHE kit identified the strain T14 as Bacillus pumilus (Table 2). Also, BLAST and phylogenetic analysis of the 16S rRNA gene sequence for the strain T15 showed $99.7 \%$ identity to the type strain NBRC $13111^{\mathrm{T}}$ of Alcaligenes faecalis and $99.1 \%$ identity to the type strain LMG $22996^{\mathrm{T}}$ of Alcaligenes aquatilis, which suggested $\mathrm{T} 15$ possibly belonged to Alcaligenes faecalis species (Figure 4).

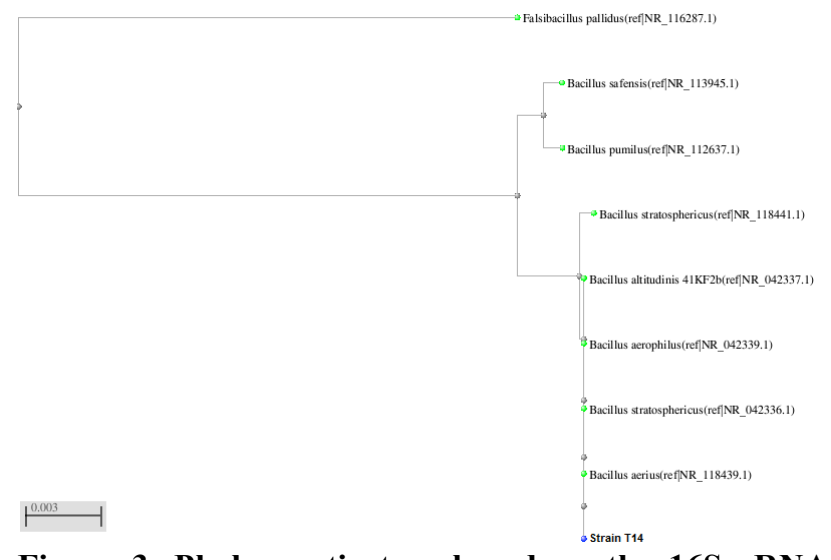

Figure 3. Phylogenetic tree based on the $16 \mathrm{~S}$ rRNA gene of the strain T14

Neighbor joining phylogenetic tree based on comparative analysis of $16 \mathrm{~S}$ rRNA gene sequences of the strain T14 and the closest related type strains. Falsibacillus pallidus was used as an outgroup. GenBank accession numbers are shown in parentheses. Only branches with the percentage of replicate trees at least $50 \%$ in the bootstrap test $(1000$ replicates) was shown. The scale bar indicates the number of substitutions per nucleotide position. 
Table 2. Differential phenotypic characteristics among the strain T14 and the related Bacillus species

\begin{tabular}{|c|c|c|c|c|c|c|}
\hline $\begin{array}{c}\text { Carbohydrate } \\
\text { metabolism }\end{array}$ & $\begin{array}{l}\text { Strain } \\
\text { T14 }\end{array}$ & $\begin{array}{l}\text { Bacillus pu- } \\
\text { milus }\end{array}$ & B. safensis & B. altitudinis & B. aerophilus & $\begin{array}{l}\text { B. strato- } \\
\text { sphericus }\end{array}$ \\
\hline References & $\begin{array}{l}\text { This } \\
\text { study }\end{array}$ & API & $\begin{array}{c}\text { Satomi et al., } \\
2006\end{array}$ & $\begin{array}{c}\text { Shivaji et al., } \\
2006\end{array}$ & $\begin{array}{c}\text { Shivaji et al., } \\
2006\end{array}$ & $\begin{array}{c}\text { Shivaji et al., } \\
2006\end{array}$ \\
\hline Glycerol & $\mathrm{W}$ & $+/-$ & & + & & \\
\hline D-arabinose & - & - & & + & + & + \\
\hline L-sorbose & - & - & & + & + & + \\
\hline L-rhamnose & - & - & & + & + & + \\
\hline Inositol & - & - & + & + & - & + \\
\hline Inulin & - & - & & + & + & + \\
\hline D-raffinose & - & - & + & - & + & + \\
\hline D-cellobiose & + & + & & + & - & + \\
\hline D-trehalose & + & + & & & + & - \\
\hline
\end{tabular}

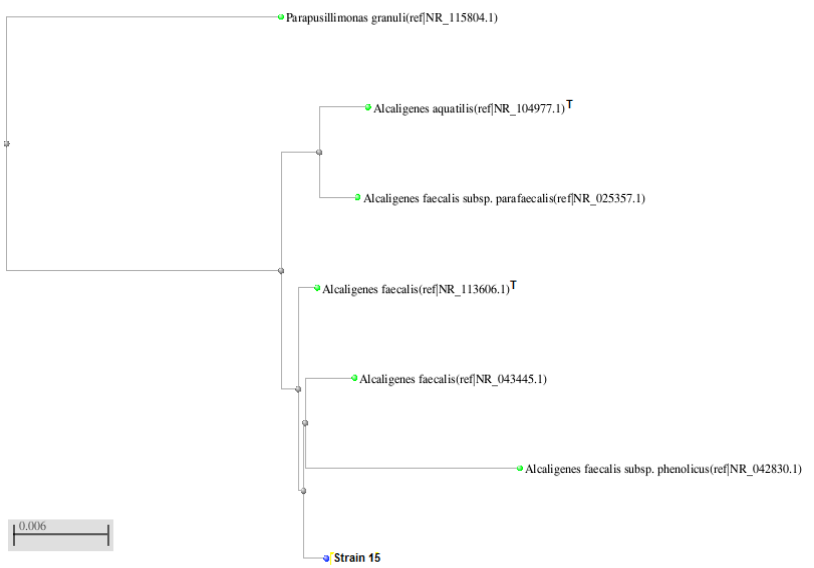

Figure 4. Phylogenetic tree based on the $16 \mathrm{~S}$ rRNA gene of the strain $\mathrm{T} 15$

Neighbor joining phylogenetic tree based on comparative analysis of $16 \mathrm{~S}$ rRNA gene sequences of the strain T15 and the closest related strains. Parapusillimonas granuli was used as an outgroup. GenBank accession numbers are shown in parentheses. Only branches with the percentage of replicate trees at least $50 \%$ in the bootstrap test $(1000$ replicates) was shown. The scale bar indicates the number of substitutions per nucleotide position. ${ }^{\mathrm{T}}$ indicates type strains.

\section{Discussion}

Endophytes are endosymbiotic microbes, often bacteria or fungi, which live within a plant for at least part of its life without causing apparent disease in the plant (Bhore et al., 2013). Endophytes have been found in all the species of plants studied to date; however, the relationship between endophytes and plants are not often well understood. Many fungal endophytes were shown to support the growth, enhance stress tolerance or improve animal resistance in the host plant (Cheplick and Faeth, 2009). Similarly, bacterial endophytes can produce bioactive compounds found in their host and have potential in providing new drugs, plant hormones, and novel natural products (Bhore et al., 2013).

In Aquilaria species, agarwood was produced in response to wounding and fungal attack, so fungal endophytes were the most considered. Molecular methods revealed succession patterns of fungi associated to wound-induced agarwood in wild Aquilaria malaccensis, which include Cunninghamella bainieri, Fusarium solani and Lasiodiplodia theobromae (Mohamed et al., 2014). Meanwhile, Aspergilus phoenicis, Penicilinum citrnum and Penicilium spp. were considered as important fungi in the formation of agarwood by Aquilaria crassna in Vietnam.

To our knowledge, it is the first time that biodiversity of bacterial endophytes associated with agarwood from Aquilaria crassna in Vietnam has been reported. A total of 26 isolates of bacterial endophytes in Aquilaria crass$n a$, which was composed of both Gram positives and negatives, both endospore and non-endospore-bearing forms, with diverse morphological characteristics in cells and colonies, was isolated and classified into seven different groups according to Bergey's system. Especially, the group II with nine isolates included Gram-positive endospore-producing bacteria (e.g. Bacillus and Clostridium), which were the most dominant group. One of these isolates, T14, was identified as Bacillus pumilus, a Gram positive, aerobic, spore-forming bacillus commonly found in soil. Another soil bacterium, T15, was identified as Alcaligenes faecalis.

Interestingly, a recent study indicated that 13 out of 18 different types of endophytic bacteria associated with seven Aquilaria species in Malaysia belonged to Bacillus species and Bacillus pumilus was also found as the most common type (Bhore et al., 2013). Many Bacillus species are found to secrete large quantities of different enzymes, so have become important species in many fields of the industry. Besides, Bacillus species can produce other natural products including bacteriocins and antibiotics, and therefore, they are potential sources of the novel natural products (Nguyen et al., 2014). Other bacterial endophytes were also found to express their antimicrobial activities including antibacterial, antifungal, and antiviral function (Castillo et al., 2002; Ding et al., 2010, 2011). Therefore, further study is necessary to develop the potential applications of Bacillus species and other isolated bacterial endophytes. Also, uncovering the relationship between Aquilaria species and associated bacteria perhaps contribute into the protection of threatened Aquilaria 
crassna species (Zhang et al., 2008), and even the deeper understanding mechanism of agarwood formation, which is now still being considered as a consequence of wounding and fungal attack only (Huang et al., 2013).

\section{Conclusions}

From the agarwood of Aquilaria crassna species in Viennam, we purified 26 isolates belonging to 7 different groups of culturable bacterial endophytes. Among them, Gram-positive endospore-producing bacteria (e.g. Bacillus) were the most dominant group. Two strains T14 and T15 were identified as Bacillus pumilus and Alcaligenes faecalis, respectively. Further research is needed in order to understand the benefits of these bacterial endophytes to Aquilaria crassna species and look for economically and pharmaceutically important bioactive compounds from these producers.

\section{References}

[1] Bhore, S.J., Preveena, J., Kandasamy, K.I. 2013. Isolation and identification of bacterial endophytes from pharmaceutical agarwood-producing Aquilaria species. Pharmacognosy Res. 5(2):134-7.

[2] Castillo, U.F., Strobel, G.A., Ford, E.J., Hess, W.M., Porter, H., Jensen, J.B., et al. 2002. Munumbicins, wide-spectrum antibiotics produced by Streptomyces NRRL 30562, endophytic on Kennedia nigriscans. Microbiology 148:267585.

[3] Chen, H.H., Zhao, G.Z., Park, D.J., Zhang, Y.Q., Xu, L.H., Lee, J.C., Kim, C.J., Li, W.J. 2009. Micrococcus endophyticus sp. nov., isolated from surface-sterilized Aquilaria sinensis roots. Int. J. Syst. Evol. Microbiol. 59(Pt 5):1070-5.

[4] Cheplick, G. P., Faeth, S. H. 2009. Ecology and Evolution of the Grass-Endophyte Symbiosis. Oxford University Press, Oxford.

[5] Ding, L., Maier, A., Fiebig, H.H., Lin, W.H., Hertweck, C. 2011. A family of multicyclic indolosesquiterpenes from a bacterial endophyte. Org. Biomol. Chem. 9:4029-31.

[6] Ding, L., Münch, J., Goerls, H., Maier, A., Fiebig, H.H., Lin, W.H., et al. 2010. Xiamycin, a pentacyclic indolosesquiterpene with selective anti-HIV activity from a bacterial mangrove endophyte. Bioorg. Med. Chem. Lett. 20:6685-7.

[7] Eurlings, M.C., van Beek, H.H., Gravendeel, B. 2010. Polymorphic microsatellites for forensic identification of agarwood (Aquilaria crassna). Forensic Sci. Int. 197(1-3):30-4.

[8] Felsenstein, J. 1985. Confidence limits on phylogenies: an approach using the bootstrap. Evolution 39:783-791.
[9] Hall, T.A. 1999. BioEdit: a user-friendly biological sequence alignment editor and analysis program for Windows 95/98/NT. Nucleic Acids Symp. Ser. 41: 95-98.

[10] Holt, J.G. 1994. Bergey's Manual of Determinative Bacteriology, 9th Edition. Williams \& Wilkins, Baltimore. ISBN 0-683-00603-7.

[11] Huang, J.Q., Wei, J.H., Zhang, Z., Yang, Y., Liu, Y.Y., Meng, H., Zhang, X.L., Zhang, J.L. 2013. Historical records and modern studies on agarwood production method and overall agarwood production method]. Zhongguo Zhong Yao Za Zhi. 38(3):302-6.

[12] Larkin, M., Blackshields, G., Brown, N., Chenna, R.M.P., McWilliam, H., Valentin, F., Wallace, I.M., Wilm, A., Lopez, R., Thompson, J.D., Gibson, T.J., Higgins, D.G. 2007. ClustalW and ClustalX version 2. Bioinformatics 23:2947-2948.

[13] Luan, X.Y., Chen, J.X., Zhang, X.H., Jia, J.T., Sun, F.R., Li, Y. 2007. Comparison of different primers for rapid detection of Vibrio parahaemolyticus using the polymerase chain reaction. Lett. Appl. Microbiol. 44: $242-247$.

[14] Moaledj, K. 1986. Comparison of Gram-staining and alternate methods, $\mathrm{KOH}$ test and aminopeptidase activity in aquatic bacteria: their application to numerical taxonomy. J. Microbiol. Methods 5:303-310.

[15] Mohamed, R., Jong, P.L., Nurul Irdayu, I. 2014. Succession patterns of fungi associated to woundinduced agarwood in wild Aquilaria malaccensis revealed from quantitative PCR assay. World J Microbiol. Biotechnol. 30(9):2427-36.

[16] Nguyen, V.D., Pham, T.T., Nguyen, T.H.T., Nguyen, T.T.X., Hoj, L. 2014. Screening of marine bacteria with bacteriocin-like activities and probiotic potential for ornate spiny lobster (Panulirus ornatus) juveniles. Fish Shellfish Immunol. 40(1):49-60.

[17] Tamura, K., Peterson, D., Peterson, N., Stecher, G., Nei, M., Kumar, S. 2011. MEGA5: molecular evolutionary genetics analysis using maximum likelihood, evolutionary distance, and maximum parsimony methods. Mol. Biol. Evol. 28:2731-2739.

[18] Tian, X.L., Cao, L.X., Tan, H.M., Han, W.Q., Chen, M., Liu, Y.H., Zhou, S.N. 2007. Diversity of cultivated and uncultivated actinobacterial endophytes in the stems and roots of rice. Microb. Ecol. 53:700707.

[19] Zhang, L., Brockelman, W.Y., Allen, M. A. 2008. Matrix analysis to evaluate sustainability: the tropical tree Aquilaria crassna, a heavily poached source of agarwood. Biological Conservation 141:16761686. 